\title{
OSTORCSAPÁS HULLÁMTERJEDÉSÉNEK LINEÁRIS ÉS NEMLINEÁRIS SZÁMÍTÁSAI
}

\author{
Szabó Tamás \\ egyetemi docens, Miskolci Egyetem, Szerszámgépészeti és Mechatronikai Intézet, \\ Robert Bosch Mechatronikai Intézeti Tanszék \\ 3515 Miskolc, Miskolc-Egyetemváros, e-mail: szabo.tamas@uni-miskolc.hu
}

\begin{abstract}
Absztrakt
A cikk egy karikás ostor csapásának kétféle végeselemes, numerikus számításaival foglalkozik. Az első modell egy egyenletesen forgó koordinátarendszerben feszitett húr lineáris hullámegyenletén alapszik. A húr elöfeszitése idöben állandó, de az ostor mentén a centrifugális eröhatás a felvett kerületi sebességnek megfelelöen a szabadvég felé fokozatosan csökken. Az ostor kezdöpontját egy idöben szinusz fél hullám szerinti elmozdulással gerjesztjük. A nemlineáris második modell az ostort síkbeli nagy elmozdulásokra képes húzott-nyomott rúdelemekkel irja le. Az ostort kezdeti sebességének elöirásával és a kezdöpontjának egyenes mentén való mozgatásával gerjesztjük. Az ostor helyzeteinek legyezö alakot mutató képe állitható elö. Mind a két modell alkalmas a csattanás, azaz ostorvég szuperszonikusnál nagyobb sebességének modellezésére.
\end{abstract}

Kulcsszavak: hullámterjedés, feszitett húr, ostor csattanás, szuperszonikus sebesség

\section{Abstract}

This article deals with two different finite element computations of the crack of a whip. The first model is based on linear wave equation of a taut string in a uniformly rotating coordinate system, using two nodes elements. The string preload is constant over time, but the centrifugal force along the whip gradually decreases toward the free tip according to the circumferential velocity. The starting point of the whip is excited by a sinusoidal half-wave displacement. The second nonlinear model describes the whip with truss elements capable of large displacements in the plane. The whip is excited by specifying its initial velocity and moving its starting point along a given line. A realistic fan-shaped image of the whip positions can be produced. Both models are suitable for modeling supersonic speeds of the whip tip, i.e. a whip crack.

Keywords: wave propagation, taut string, whip crack, supersonic speed

\section{Bevezetés}

A mechanikai hullámok terjedése a természetben gyakran katasztrofális jelenségekkel járnak. Ilyenek a földrengések és az azok által az óceánokban gerjesztett hullámok, azaz a cunamik is. Az óceánok vízoszlopának és a gravitációs gyorsulás szorzatából számítható a cunami hullám terjedési sebességének a négyzete. A Csendes-óceán átlagos $4000 \mathrm{~m}$ mélységénél a hullámterjedés sebessége kb. $200 \mathrm{~m} / \mathrm{s}$. A partok közelében a fokozatosan csökkenő vízmélységnél a terjedési sebessége lecsökken, míg a hullám magassága rendkívül megnő, ami katasztrófát okozhat a partmenti településeken.

A cikk egy a cunamival analóg hullámterjedési jelenséggel, akevésbé veszélyes ostor csattanásával foglalkozik. A csikósostornál megfelelő csukló mozdulattal keltett hullám csattanását, csergetésnek ne- 
vezik. Az ostor a különböző állatok terelésével foglalkozók számára fontos munkaeszköz. Felépítésükben az a közös, hogy a nyéltől kezdődően a többszörösen fonott ostor vastagsági mérete fokozatosan csökken a hossz mentén. Többnyire egy vagy két lépcsőben kisebb átmérőjü és folyóméter súlyú szíjjal vagy rafia fonattal folytatódik, aminek a végén a csattanást adó vékony rojtos suhogó/sudár van.

A bivalyostor hullámterjedését [1], [2] cikkek optikai mérésekkel és elméleti számításokkal is vizsgálták, a csattanás jelenségét az ún. hurok hullámterjedéssel írták le. A rúd mechanikai modell a hajlítási igénybevételt is figyelembe vette.

Jelen cikk lineáris és nemlineáris végeselemes számításokra alapozva csak numerikus számításokkal foglalkozik. A lineáris modell a feszített húr kiselmozdulásra alapozott hullámegyenletére épül, ahol a hullámterjedés sebességét az ostor adott keresztmetszetében ébredő feszítőerő és a folyóméter tömegének hányadosának négyzetgyöke határozza meg. A számításoknál feltételezzük, hogy az ostor pontjai alapvetően körpályán mozognak, a feszítőerő pedig a centrifugális hatásból származik.

A nemlineáris modell az ostor nagy elmozdulását szintén a hajlítási igénybevétel elhanyagolásával, tetszőleges síkbeli mozgás feltételezésével, realisztikusan írja le. A feszítőerő a pillanatnyi konfigurációban az inercia erőből származik. Az ostornyél végének előírt pályája és az ostor adott kezdősebessége határozza meg az ostor mozgását és az elindított hullám terjedését.

A cikk második fejezete a hullámterjedés lineáris modelljét mutatja be. A harmadik fejezet a nemlineáris modell végeslemes formalizmusát vázolja. A 4. fejezet a kétféle modellel kapott numerikus eredményeket ismerteti. Az ötödik fejezet a kutatási következtetéseket foglalja össze.

\section{Az ostorcsapás hullámterjedésének lineáris modellje}

A csikósostor csergetését minding megelőzi az ostor körpályán való mozgatása, amikor kellő sebességre tesz szert, ahhoz, hogy a feszített húr állapota a centrifugális erő hatására létre jöjjön. Az ostor a nyélnél $R_{1}$, a végén a sudár $R_{2}$ sugarú körökön, rendre $v_{1}$, illetve $v_{2}$ sebességgel mozognak. A lineáris modellt, így célszerủen az ostorral együtt forgó koordinátarendszerben írjuk le, amelyben az ostor egy $L$ hosszúságú egyenes feszített húr, az ívhossz mentén lineárisan csökkenő keresztmetszettel. A feszített húrban a hullámterjedés $c_{h}^{2}(r)$ hangsebességének négyzete az $N(r)$ feszítőerő és az $A(r) \rho$ fajlagos tömeg hányadosaként számítható [3]:

$$
\begin{gathered}
c_{h}^{2}(r)=\frac{N(r)}{A(r) \rho}=\frac{1}{\rho A(r)} \int_{R}^{R_{2}} \frac{\rho A(r) v^{2}(r)}{r} d r= \\
=\frac{1}{\left(A_{2}-\frac{r-R_{1}}{L}\left(A_{2}-A_{2}\right)\right)} \int_{R}^{R_{2}} \frac{\left(A_{2}-\frac{r-R_{1}}{R_{2}-R_{1}}\left(A_{2}-A_{1}\right)\right)\left(v_{1}+\left(\frac{v_{2}-v_{1}}{L}\right)\left(r-R_{1}\right) r\right)^{2}}{r} d r
\end{gathered}
$$

ahol $A_{1}, A_{2}$ rendre az ostor keresztmetszete a nyélnél, illetve a sudárnál.

A feszített húr, azaz az ostor hullámegyenlete [2]:

$$
\frac{\partial}{\partial r}\left(c_{h}^{2}(r) \frac{\partial u_{\varphi}}{\partial r}\right)=\frac{\partial^{2} u_{\varphi}}{\partial t^{2}}, \quad R_{1}<r<R_{2},
$$

ahol $u_{\varphi}$ az ostor ívhosszára merőleges, a hullám alakjából származó elmozdulás, amelyről feltételezzük, hogy a forgás síkjába esik. 
A (3) differenciálegyenlethez a Hamilton elv alapján az alábbi variációs egyenlet rendelhető:

$$
\int_{t 1}^{t 2}(\delta T-\delta U) d t=0, \quad \delta u_{\varphi}(r, t)=0, \quad R_{1} \leq r \leq R_{2}, \quad t=t_{1}, t_{2},
$$

ahol $\delta u_{\varphi}(r, t)=0$ az elmozdulás variációja, $T(t)$ és $U(t)$ az egységnyi fajlagos tömeggel számolt „kinetikai energia” és ,alakváltozási energia”,

$$
\begin{gathered}
T(t)=\frac{1}{2} \int_{R_{1}}^{R_{2}}\left[\frac{\partial u_{\varphi}(r, t)}{\partial t}\right]^{2} d r, \\
U(t)=\frac{1}{2} \int_{R_{1}}^{R_{2}} c_{h}^{2}(r)\left[\frac{\partial u_{\varphi}(r, t)}{\partial r}\right]^{2} d r,
\end{gathered}
$$

a $t_{1}, t_{2}$ rendre a megfigyelés kezdő- és végső időpontjai.

Az $R_{2}-R_{1}$ tartományt azonos hosszúságú $n_{e}$ számú két csomópontú ív szakaszra osztjuk, amelyen a $u_{\varphi}$ elmozdulást az alábbi módon közelítjük:

$$
u_{\varphi}^{e}(r, t)=\mathbf{H}^{e}(r) \mathbf{q}^{e}(t)
$$

ahol $\mathbf{H}^{e}$ a közelítő függvények mátrixa, és $\mathbf{q}^{\mathbf{e}}$ a csomóponti elmozdulások vektora:

$$
\mathbf{H}^{e}(r)=\left[\left(1-\frac{r}{L^{e}}\right) \frac{r}{L^{e}}\right] ; \quad \mathbf{q}^{e T}(t)=\left[\begin{array}{ll}
u_{1 \varphi}^{e}(t) & u_{2 \varphi}^{e}(t)
\end{array}\right],
$$

$L^{e}$ egy elem hossza, a $u_{1 \varphi}^{e}, u_{2 \varphi}^{e}$ a két végpontjának kerületi irányú elmozdulása.

Behelyettesítve (6), (7) kifejezéseket (4), (5) összefüggésekbe származtathatjuk az elem $\mathbf{M}^{e}$ tömegmátrixát és $\mathbf{K}^{e}$ merevségi mátrixát:

$$
\mathbf{M}^{e}=\left[\begin{array}{ll}
\frac{1}{3} & \frac{1}{6} \\
\frac{1}{6} & \frac{1}{3}
\end{array}\right] ; \quad \mathbf{K}^{e}=c_{h}^{2}\left(r^{e}\right)\left[\begin{array}{cc}
1 & -1 \\
-1 & 1
\end{array}\right],
$$

ahol $c_{h}^{2}\left(r^{e}\right)$ az adott elem átlagos hangsebességének négyzete, amely az $r_{1}, r_{2}$ helyeken lévő csomópontok és az $r_{k}$ helyen lévő felezőpont alapján a Simpson formulával is meghatározható:

$$
c_{h}^{2}\left(r^{e}\right)=\frac{1}{L^{e}} \int_{r_{1}}^{r_{2}} c_{h}^{2}(r) d r=\frac{c_{h}^{2}\left(r_{1}\right)+4 c_{h}^{2}\left(r_{k}\right)+c_{h}^{2}\left(r_{2}\right)}{6}
$$

A (3) variációs elvbe visszahelyettesítve az (6) - (9) összefüggéseket, átalakítások után az alábbi mozgásegyenlet adódik:

$$
\mathbf{M} \ddot{\mathbf{q}}+\mathbf{K q}=\mathbf{0},
$$

ahol $\mathbf{M}=\sum_{1}^{n_{e}} \mathbf{M}^{e}, \mathbf{K}=\sum_{1}^{n_{e}} \mathbf{K}^{e}$ rendre a szerkezeti tömeg- és merevségi mátrix, amelyek a végeselem módszernél alkalmazott elemmátrixok összegzése alapján, a q, $\mathbf{q}$ a csomóponti elmozdulások és csomóponti gyorsulások vektorai.

Egy szerkezetnek mindig van belső csillapítása, amelyet kényelmi okokból a Rayleigh-féle $\alpha, \beta$ csillapítási tényezőkkel, a tömeg és merevségi mátrix kombinációjaként szokás megadni $\mathbf{C}=\alpha \mathbf{M}+\beta \mathbf{K}$. 


$$
\mathbf{M} \ddot{\mathbf{q}}+\mathbf{C} \dot{\mathbf{q}}+\mathbf{K q}=\mathbf{0},
$$

Az ostornak a nyélhez kapcsolódó 1-es számú csomópontjának mozgását időben változó, egyetlen szinusz fél hullámmal $u_{1 \varphi}(t)=0,2 \sin (\pi t / 0,005)$ írjuk elö, amelyböl a 2-dik csomópontban $f_{\text {kin }}$ kinematikai gerjesztő erő származik az (1) egyenlet és a (8) mátrixok 2,1 indexü együtthatóiból.

$$
\begin{aligned}
f_{\text {kin }}(t)=-\frac{0,2}{6} & \left(\frac{\pi}{0,005}\right)^{2} \sin \left(\frac{\pi t}{0,005}\right)+0,2\left(\frac{\alpha}{6}-\beta c_{h}^{2}\left(r^{1}\right)\right) \cos \left(\frac{\pi t}{0,005}\right) \\
& -c_{h}^{2}\left(r^{1}\right) 0,2 \sin \left(\frac{\pi t}{0,005}\right)
\end{aligned}
$$

Az adott elmozdulás miatt az $\mathbf{M}, \mathbf{C}, \mathbf{K}$ mátrixok első sorait és oszlopait töröljük és az $f_{\text {kin }}(t)$ erőt az $\hat{\mathbf{f}}_{\text {kin }}$ egyébként zérus oszlopvektorának első elemébe töltjük, miután az egyenlet az alábbi alakot ölti:

$$
\widehat{\mathbf{M}} \ddot{\mathbf{q}}+\widehat{\mathbf{C}} \dot{\mathbf{q}}+\widehat{\mathbf{K}} \mathbf{q}=\hat{\mathbf{f}}_{\boldsymbol{k i n}}(t),
$$

A (13) közönséges differenciálegyenletet Newmark-féle trapéz módszerrel [4] oldjuk meg.

\section{Az ostorcsapás hullámterjedésének nemlineáris modellje}

Az ostor hullámmozgását leíró nemlineáris dinamikai végeselemes egyenleteit jelen szerző korábbi [5] cikkében részletesen publikálta, ezért itt csak a legfontosabb megfontolásokat, összefüggéseket a cikk megismételhetőségének céljából foglaljuk össze. Az ostort ún. húzott-nyomott síkbeli két csomópontú rúdelemekkel diszkretizáljuk nagyon hasonlóan a 2. fejezetben ismertetettek szerint, azzal a lényeges különbséggel, hogy a csomópontok a sík mind a két irányában elmozdulhatnak, nemcsak az elemre merőlegesen.

Az elemek lokális koordinátarendszerben értelmezett $\overline{\mathbf{M}}_{e}$ tömeg, a $\overline{\mathbf{K}}_{L e}$ lineáris és $\overline{\mathbf{K}}_{G e}$ geometriai merevségi mátrixai, valamint az $\overline{\mathbf{f}}_{\sigma e}$ belsőerők tehervektora az alábbi alakúak:

$$
\begin{gathered}
\overline{\mathbf{M}}_{e}=\frac{\rho^{t} A^{t}\left(r_{k}^{e}\right) L_{e}^{t}}{6}\left[\begin{array}{llll}
2 & 0 & 1 & 0 \\
0 & 2 & 0 & 1 \\
1 & 0 & 2 & 0 \\
0 & 1 & 0 & 2
\end{array}\right] \\
\overline{\mathbf{K}}_{L e}=\frac{A^{t}\left(r_{k}^{e}\right) E}{L_{e}^{t}}\left[\begin{array}{cccc}
1 & 0 & -1 & 0 \\
0 & 0 & 0 & 0 \\
-1 & 0 & 1 & 0 \\
0 & 0 & 0 & 0
\end{array}\right], \quad \overline{\mathbf{K}}_{G e}=\frac{A^{t}\left(r_{k}^{e}\right) \sigma_{11}^{t}}{L_{e}^{t}}\left[\begin{array}{cccc}
1 & 0 & -1 & 0 \\
0 & 1 & 0 & -1 \\
-1 & 0 & 1 & 0 \\
0 & -1 & 0 & 1
\end{array}\right], \\
\overline{\mathbf{f}}_{\sigma e}=A^{t}\left(r_{k}^{e}\right) \sigma_{11}^{t}\left[\begin{array}{c}
-1 \\
0 \\
1 \\
0
\end{array}\right],
\end{gathered}
$$

ahol a $t$ felsőindex az egyes mennyiségeknél az aktuális időben az elemen értelmezett geometriai, anyagjellemzőket jelenti, a $\sigma_{11}^{t}$ jelöli a rúdelem irányában ébredő normálfeszültséget. Az elemek a lokális koordinátarendszerből a globális rendszerbe transzformálhatók az alábbi $\mathbf{T}^{e}$ transzformációs mátrixszal a csomópontok aktuális $x_{i}, x_{j}, y_{i}, y_{j}$ globális koordinátáival és az $L_{e}^{t}$ hosszával kifejezve: 


$$
\mathbf{T}^{e}=\left[\begin{array}{ccrl}
\frac{x_{j}-x_{i}}{L_{e}^{t}} 1 & \frac{y_{j}-y_{i}}{L_{e}^{t}} & 0 & 0 \\
-\frac{y_{j}-y_{i}}{L_{e}^{t}} & \frac{x_{j}-x_{i}}{L_{e}^{t}} & 0 & 0 \\
0 & 0 & \frac{x_{j}-x_{i}}{L_{e}^{t}} 1 & \frac{y_{j}-y_{i}}{L_{e}^{t}} \\
0 & 0 & -\frac{y_{j}-y_{i}}{L_{e}^{t}} & \frac{x_{j}-x_{i}}{L_{e}^{t}} 0
\end{array}\right]
$$

A transzformációk és az elemek speciális végeselemes összegzése után figyelembe vesszük az ostor nyelénél a csomópont kinematikai előírását az $\hat{\mathbf{f}}_{\text {kin }}$ kinematikai tehervektorban és az alábbi mozgásegyenletet kapjuk

$$
\widehat{\mathbf{M}}^{t+\Delta t} \ddot{\mathbf{q}}+\widehat{\mathbf{C}}^{t+\Delta t} \dot{\mathbf{q}}+\widehat{\mathbf{K}}^{t+\Delta t} \mathbf{q}=\hat{\mathbf{f}}_{\boldsymbol{k i n}}(t+\Delta t)-\hat{\mathbf{f}}_{\sigma} .
$$

A (18) egyenlet baloldalán ismét a Rayleigh-féle csillapítást alkalmazzuk hasonlóan a lineáris esetnél alkalmazott módon $\widehat{\mathbf{C}}^{t+\Delta t}=\alpha \widehat{\mathbf{M}}^{t+\Delta t}+\beta \widehat{\mathbf{K}}^{t+\Delta t}$, a jobboldalon található a $\hat{\mathbf{f}}_{\sigma}$ a belső erők teher vektora. A lineáris feladathoz hasonlóan itt is a Newmark-féle módszert alkalmazzuk a (18) egyenlet numerikus integrálásához, de ebben az esetben minden időlépésben egy egyensúlyi iterációval egészül ki az algoritmus, amíg a jobboldal két vektorának különbsége zérussá nem válik. A q oszlopvektor a csomóponti elmozdulások növekményét tartalmazza, amelyeket összegezve az iteráció végén a tényleges csomóponti elmozdulásokat adják.

\section{Numerikus számítások}

A lineáris és nemlineáris modellel vizsgált csikósostor hossza $L=4 \mathrm{~m}$, a keresztmetszete az ostornyél $A_{1}=160 \mathrm{~mm}^{2}$, a végpontban a sudárnál $A_{2}=2 \mathrm{~mm}^{2}$. Az ostorbör rugalmas anyagának Young modulusa $E=2000 \mathrm{MPa}$.

A lineáris modellezés során feltételezzük, hogy az ostor pontjai körpályán mozognak, az ostornyélnél lévő kezdőpont $R_{1}=0,8 \mathrm{~m}$, a sudárnál a végpont pedig $R_{2}=4,8 \mathrm{~m}$ sugáron. A sebesség az ostor mentén lineárisan növekszik a kezdőponti $v_{1}=32 \mathrm{~m} / \mathrm{s}$-tól a végponti $v_{2}=64 \mathrm{~m} / \mathrm{s}-$ ig. Ez a lineáris kép a hullám áthaladása alatt, természetesen az adott helyen megváltozik. Az ostort a hossza mentén $n_{e}=$ 1000 két csomópontú elemet tartalmaz, a Newmark-féle integrálás egyenközü időlépése $\Delta t=0,5$. $10^{-4} \mathrm{~s}$. Az önkényesen választott Rayleigh-féle csillapítás értékei: $\alpha=0, \beta=10^{-6}$. A 2. fejezetben közöltek szerint az $u_{1 \varphi}(t)=0,2 \sin (\pi t / 0,005)$ függvény szerinti egyetlen fél hullámmal gerjesztjük a rendszert. A 2. fejezetben ismertetett algoritmussal kapott, az ostor mentén haladó hullámot az 1. ábra szemlélteti. A fél hullám amplitúdója az előrehaladással egyre növekszik, és a végén jól láthatóan megtörténik az ostorcsapás. Megfigyelhető, hogy a hullám előrehaladásával a sebessége és a szélessége egyaránt csökken. A 2. ábrán az ostor felező, kék színü marker pontjának és a pirossal jelzett végpontjának abszolút sebességét, azaz a forgó koordinátarendszerbeli szállító és a relatív sebességek összegeit, rendre kék és piros görbékkel ábrázoltuk. A végpont, azaz a sudár sebessége a 331,5 m/s értéket meghaladó szuperszonikus tartományba esik, amely az ostor csattanásával jár. 


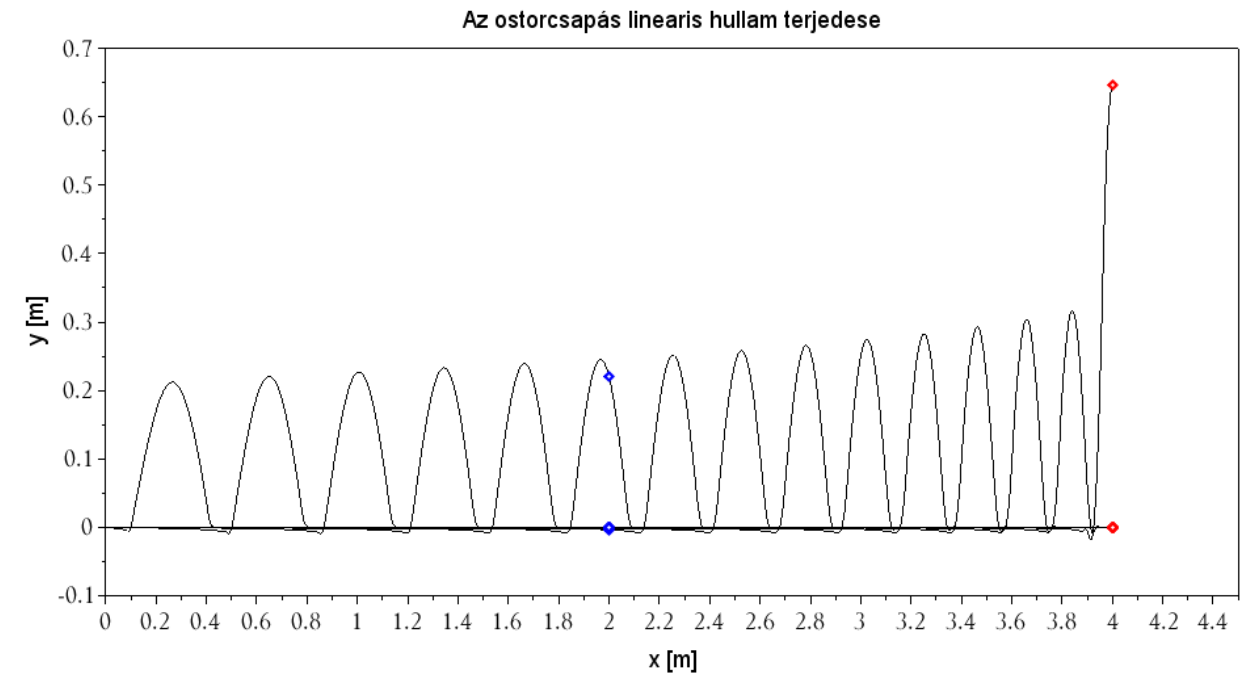

1. ábra. Lineáris modell: hullámterjedés (a felezöpont kék, a végpont piros)

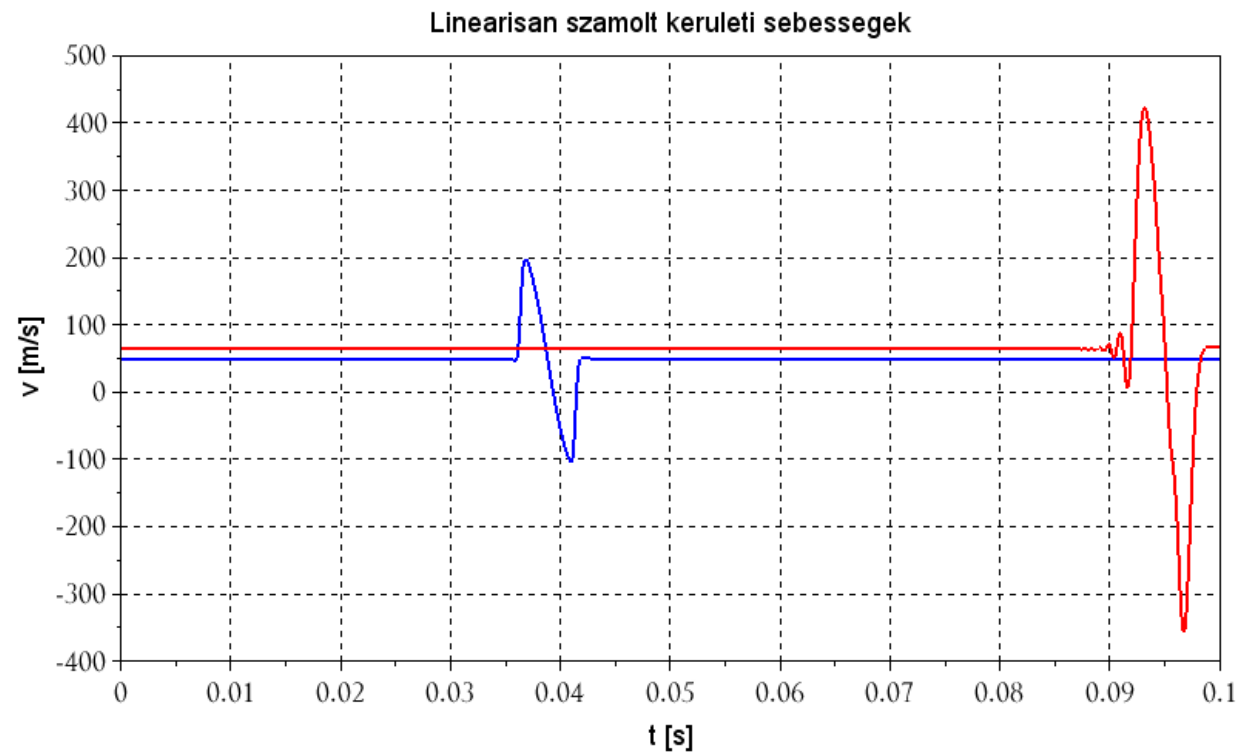

2. ábra. Lineáris modell: kék vonal a felezöpont, piros a végpont kerületi irányú sebessége

A nemlineáris modell az ostort az $L=4 \mathrm{~m}$ hossza mentén $n_{e}=25$ két csomópontú azonos hosszúságú elemet tartalmaz. A kezdő sebesség ostor menti eloszlása megegyezik a lineáris rendszerben felvett lineáris eloszlási képpel: a kezdőponti $v_{1}=32 \mathrm{~m} / \mathrm{s}$ értékről a végpontig $v_{2}=64 \mathrm{~m} / \mathrm{s}-$ ig növekszik. Az önkényesen választott Rayleigh-féle $\alpha=0.005, \beta=0.001$ csillapítás azt a célt szolgálja, hogy a gyakorlatban nem tapasztalt nemkívánatos nagyfrekvenciás oszcillációt kiszűrje. 


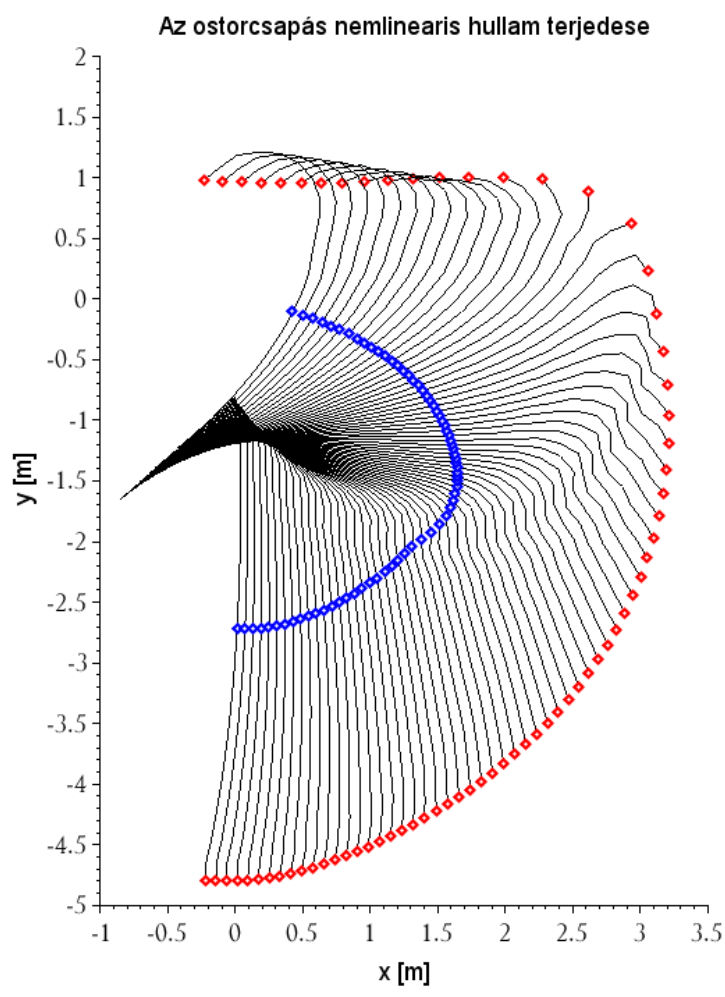

3. ábra. Nemlineáris modell: Az ostor síkbeli, óramutató járással ellenkezö mozgása

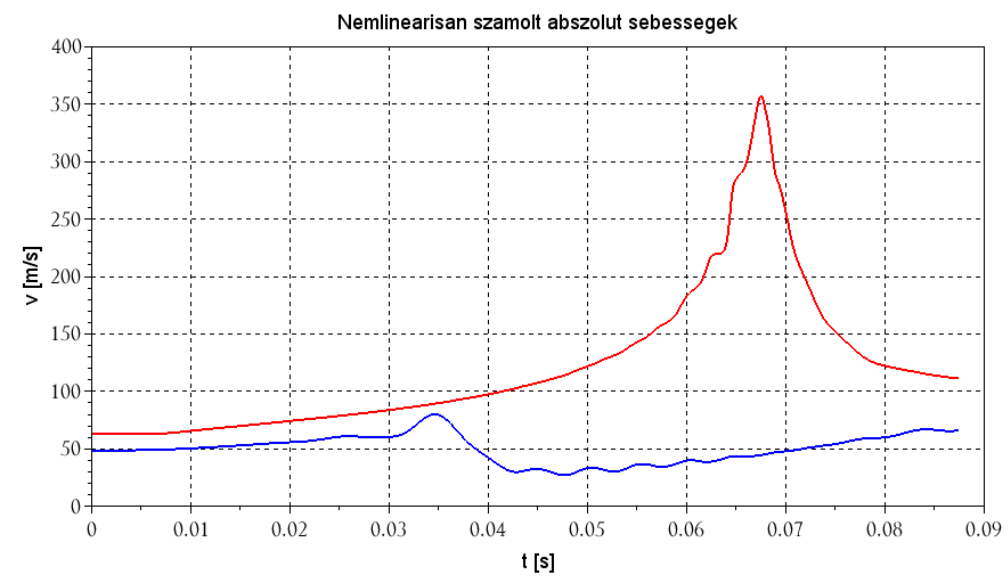

4. ábra. Nemlineáris modell: kék vonal a felezöpont, piros a végpont kerületi irányú sebessége

A nyélnél, az ostor kezdőpontja egy a függőleges egyenessel 45 fokot bezáró egyenes mentén, $i_{t}$ időlépés számától lineárisan függő $\Delta s=10^{-3}+i_{t} \cdot 10^{-6}$ egyre nagyobb lépésnagysággal mozog, hogy 
az ostor feszessége mindig fennálljon. A Newmark-féle integrálás egyenközü időlépése $\Delta t=1,25$. $10^{-4} \mathrm{~s}$, az egyensúlyi iteráció maximális száma $n_{i t e r}=25$.

A 3. fejezetben ismertetett nemlineáris végeselemes eljárással kapott ostormozgást a 3. ábra szemlélteti. Az ostor alsó, közel függőleges helyzetből indulva az óramutató járásával ellentétes irányba halad az adott kezdeti sebesség és a nyélnél lévő kezdőpont ferdevonalú mozgatása következtében. Kék színü marker jelzi az ostor hosszának felezőpontját, a végpontot, azaz a sudárt piros marker jelzi. Az ostor mentén a hullámterjedés és a csapás helye jól beazonosítható. A 4. ábra a kék felező és a piros végpontok sebességeit a színeiknek megfelelő vonalakkal ábrázolja. A nemlineáris modell, a lineárishoz hasonló maximális értékü, a szuperszonikus tartományba eső sebességet mutat a sudár csattanásakor, de ezután itt nem figyelhető meg a sudár közel szimmetrikus negatív sebessége.

\section{5. Összefoglalás}

A cikk egy csikósostor csattanásának lineáris és nemlineáris modellezését tárgyalta az ostor hajlítási merevségének elhanyagolásával. A lineáris modell nagy előnye, hogy igen sürü végeselemes felosztással, kis időlépésekkel, nagy pontossággal és relatíve gyorsan elvégezhető, az adott feltételezések mellett. Hátránya, hogy az ostor feltételezett körpályán való mozgása korlátozza a „tetszőleges” ostor csattanások szimulálását.

A nemlineáris modellel csak relatíve durva felosztás mellet végezhetünk számításokat, mert a numerikus algoritmus együttható mátrixa rosszul kondicionálttá válik sủrü felosztásnál. Ellenben a síkbeli mozgás lehetősége teljesen realisztikus legyező képet mutató ostormozgások modellezésére is alkalmas. Mindkét modell az ostor csattanását, a sudár szuperszonikus sebességét jósolta meg. A modell tovább fejleszthető, a légellenállás megfelelő, azaz a szuperszonikus tartományban való megváltozásának figyelembe vételével.

\section{Köszönetnyilvánítás}

A cikkben ismertetett kutató munka az EFOP-3.6.1-16-2016-00011 jelü „Fiatalodó és Megújuló Egyetem - Innovatív Tudásváros - a Miskolci Egyetem intelligens szakosodást szolgáló intézményi fejlesztése" projekt részeként - a Széchenyi 2020 keretében - az Európai Unió támogatásával, az Európai Szociális Alap társfinanszírozásával valósul meg.

\section{Irodalom}

[1] Goriely, A. and McMillen, T.: Shape of a cracikng whip, Physical Rewiew Letters, Vol. 88, Num. 24, (2002) pp.244301.1-244301.4. https://doi.org/10.1103/PhysRevLett.88.244301

[2] McMillen, T. and Goriely, A.: Whip Waves, Physica D 184 (2003), pp. 192-225, https://doi.org/10.1016/S0167-2789(03)00221-5

[3] Meirovitch, L.: Fundamentals of Vibrations, McGRAW-HILL, Singapore, 2001., ISBN 0-07118174-1

[4] Bathe K-J: Finite Element Procedures, Prentice-Hall, 1986., ISBN 0-13-301458-4

[5] Mourane, H, Szabó, T.: Linear and Nonlinear Dynamical Analysis of a Crane Modell, Pollack Periodica 15(2):82-93. https://doi.org/10.1556/606.2020.15.2.8 